\title{
Effect of dentinal surface preparation on bond strength of self-etching adhesive systems
}

\section{Efeito da preparação da superfície dentinária na resistência de união de adesivos autocondicionantes}

\author{
Patrícia Itocazo Rocha* \\ Alessandra Bühler Borges** \\ José Roberto Rodrigues*** \\ César Augusto Galvão Arrais* \\ Marcelo Giannini ${ }^{* * * *}$
}

\begin{abstract}
The aim of this study was to evaluate the effects of dentin surface treatments on the tensile bond strength (TBS) of the self-etching primer Clearfil SE Bond (CSE) and the one-step self-etching One-Up Bond F (OUB). The exposed flat dentin surfaces of twenty-four sound third molars were prepared with diamond bur at high-speed, carbide bur at low-speed or wet ground with \#600 grit SiC paper. The adhesive systems were applied to the dentin surfaces and light-cured according to the manufacturers' instructions. A 6-mm high composite crown was incrementally built-up and each increment was light-cured for 40 seconds. After being stored in water $\left(37^{\circ} \mathrm{C} / 24 \mathrm{~h}\right)$, the samples were serially sectioned parallel to the long axis, forming beams $(\mathrm{n}=20)$ with a cross-sectional area of approximately $0.8 \mathrm{~mm}^{2}$. The specimens were tested in a Universal Testing Machine at $0.5 \mathrm{~mm} / \mathrm{min}$. The cross-sectional area was measured and the results $(\mathrm{MPa})$ were analyzed by two-way ANOVA and Tukey Test $(\mathrm{p}<0.05)$. Overall, the groups treated with CSE exhibited the highest TBS for all surface treatments. Dentin surfaces prepared with carbide bur at low speed reduced TBS in the CSE group; however, OUB was not affected by surface treatments. The effect of surface abrasive methods on TBS was material-dependent.
\end{abstract}

DESCRIPTORS: Dentin-bonding agents; Dentin; Tensile strength.

\begin{abstract}
RESUMO: O objetivo deste estudo foi avaliar os efeitos de tratamentos superficiais da dentina na resistência de união (RU) de dois sistemas adesivos autocondicionantes, Clearfil SE Bond (CSE) e One-Up Bond F (OUB). Superficies dentinárias planificadas de vinte e quatro terceiros molares foram preparadas com pontas diamantadas em alta rotação, brocas "carbide" em baixa rotação ou abrasionadas com lixas de SiC (\#600). Os adesivos foram aplicados e fotoativados de acordo com as instruções dos fabricantes. Um bloco de compósito foi construído nas superficies tratadas e cada incremento de resina foi fotoativado por 40 segundos. Após armazenamento em água $\left(37^{\circ} \mathrm{C} / 24 \mathrm{~h}\right)$, os dentes restaurados foram serialmente seccionados paralelamente ao seu longo eixo para obtenção de espécimes com área de secção transversal de aproximadamente $0,8 \mathrm{~mm}^{2}(\mathrm{n}=20)$. Os espécimes foram testados em máquina universal de ensaios $(0,5 \mathrm{~mm} / \mathrm{min})$. A área de união foi mensurada e os resultados (MPa) foram analisados pela ANOVA ( 2 fatores) e pelo teste de Tukey $(p<0,05)$. Os grupos restaurados com o adesivo CSE mostraram os maiores valores de RU para todos os tratamentos. A superficie da dentina preparada com brocas carbide em baixa rotação reduziu a RU para o adesivo CSE; entretanto, a RU do adesivo OUB não foi afetada pelos tratamentos. O efeito da preparação da dentina na RU foi material-dependente.
\end{abstract}

DESCRITORES: Adesivos dentinários; Dentina; Resistência à tração.

\section{INTRODUCTION}

The formation and treatment of the smear layer is a matter of interest for bonding procedures in order to obtain an effective bonding to dentin ${ }^{3}$. Containing particles of enamel and dentin, the smear layer is created whenever a tooth is abraded with abrasive papers, cut with rotary or hand instruments ${ }^{5,12}$. Because of its inherent weak interaction with the underlying dentin, the smear layer can be removed with phosphoric acid, or modified with acidic solutions such as self-etching adhesive systems ${ }^{8}$.

*Graduate Students; **Substitute Professor; ${ }^{* * * A s s i s t a n t ~ P r o f e s s o r ~-~ D e p a r t m e n t ~ o f ~ R e s t o r a t i v e ~ D e n t i s t r y, ~ S a ̃ o ~ P a u l o ~ S t a t e ~}$ University.

****Associate Professor, Department of Restorative Dentistry, School of Dentistry of Piracicaba, State University of Campinas. 
Rocha PI, Borges AB, Rodrigues JR, Arrais CAG, Giannini M. Effect of dentinal surface preparation on bond strength of self-etching adhesive systems. Braz Oral Res 2006;20(1):52-8.

However, since these acidic solutions should diffuse and infiltrate through the smear layer to reach the underlying intact dentin, a thick or resistant smear layer might compromise the quality of the bond ${ }^{17}$. Although most of the laboratory studies commonly use silicon carbide abrasive papers to simulate the creation of the smear layer on dentin surfaces, the most common rotary instruments used for cavity preparations are steel burs, tungsten carbide and diamond burs, which might create smear layers varying in thickness, roughness, density and amount of particles of tooth structure $2,5,7,11,12,15,19$.

Some studies have given conflicting reports about the influence of surface preparation methods on bond strength ${ }^{9,16}$. Considering the hypothesis that the differences between these reports might be related to the differences among compositions of self-etching systems as well as to the type of burs used, more information is needed to determine an adequate and safe clinical use of self-etching adhesive systems. This study evaluated the effect of the dentin surface treatments with \#600-grit $\mathrm{SiC}$ paper, high-speed diamond bur or low-speed tungsten carbide bur on the bond strength to dentin of two self-etching adhesive systems. The null hypothesis tested was that the method used to produce the smear layer does not affect the tensile bond strength (TBS) of the self-etching adhesive systems.

\section{MATERIALS AND METHODS}

Twenty-four sound human third molars, stored in $0.05 \%$ thymol solution for up to four weeks after extraction, were used in this study. The teeth were obtained after informed consent was obtained from the patients and after the research protocol was analyzed and approved by the Ethical Research Committee (058/2003 - PH/ CEP), School of Dentistry of São José dos Campos, State University Julio Mesquita Filho (UNESP), Brazil. The teeth were cleaned of gross debris and placed in distilled water for 24 hours prior to the restorative procedures.

Occlusal enamel was removed using a watercooled diamond disc (8859-010, Brasseler, Lemgo, Germany) in a hard tissue-sectioning machine (Labcut Extec Corp., Enfield, CT, USA) to expose a superficial flat dentin surface parallel to the occlusal surface. The teeth were randomly assigned to three groups according to the type of dentin treatment: a diamond bur (882.314.012, Bras- seler, Lemgo, Germany), a tungsten carbide bur (H21LR.314.010, Brasseler) or \#600-grit SiC paper (3M do Brasil, Sumare, SP, Brazil).

The diamond bur was mounted on a dental turbine (Extra Torque 605, Kavo Dental GmbH, Biberach, Germany) and applied at high-speed, under water cooling; the tungsten carbide bur was mounted on a micromotor handpiece (L-Motor 181 DB INTRAmatic, KaVo Dental GmbH) and applied at low-speed under air-water spray. The dentin surface preparations were performed by the same operator that gently passed the burs 30 times on the dentin surface, under copious airwater spray. For the experimental groups in which dental turbine or micromotor handpiece were not used, the dentin was abraded with a \#600-grit $\mathrm{SiC}$ paper, on a polishing machine (DP 10, Struers Inc., Westlake, $\mathrm{OH}, \mathrm{USA}$ ) under cooling water for 15 seconds $^{3,14}$.

Following dentin preparation, the self-etching primer adhesive system Clearfil SE Bond (Kuraray Medical Inc., Kurashiki, Okayama, Japan) and the one-step self-etching adhesive system One-Up Bond F (Tokuyama Dental Corp., Shunan city, Yamaguchi, Japan) were applied to the dentin surfaces and light-cured according to the manufacturers' instructions. A $6 \mathrm{~mm}$-high composite resin "crown" (TPH Spectrum, Dentsply Caulk, Milford, DE, USA) was then incrementally built-up on the dentin surface and each resin layer was light-cured for 40 seconds with an XL 3000 light-curing unit (3M ESPE, St. Paul, MN, USA).

After storage in distilled water $\left(37^{\circ} \mathrm{C} / 24 \mathrm{~h}\right)$, the teeth were vertically and serially sectioned in mesiodistal and buccolingual directions (4 sections of each side, approximately $0.9 \mathrm{~mm}$ wide and $0.9 \mathrm{~mm}$ thick) with a diamond saw (Isomet 1000, Buehler Ltd., Lake Bluff, IL, USA) to obtain some (nine) beams with a cross-sectional area of approximately $0.8 \mathrm{~mm}^{2}$. Five beams were selected from each tooth, resulting in twenty specimens per group to be tested $(n=20)$. The five selected specimens were: one from the center and four from the extremities. Each beam was carefully attached to the grips of a microtensile testing device (Cometa, Piracicaba, SP, Brazil) with cyanoacrylate adhesive (Zapit, DVA, Corona, CA, USA) and tested under tension in a Universal Testing Machine (4411, Instron Corp., Canton, MA, USA) at a crosshead speed of $0.5 \mathrm{~mm} / \mathrm{min}$ until failure occurred. After testing, the cross-sectional area of each specimen was measured with a digital caliper (727, Starrett Ind. Com. Ltda., Itu, SP, Brazil) and tensile bond 
Rocha PI, Borges AB, Rodrigues JR, Arrais CAG, Giannini M. Effect of dentinal surface preparation on bond strength of self-etching adhesive systems. Braz Oral Res 2006;20(1):52-8.

strength was calculated. The data were expressed in MPa and analyzed by two-way ANOVA and Tukey test $(\mathrm{p}<0.05)$. Fractured surfaces were examined under SEM to determine the failure pattern.

Eighteen additional third molars were prepared for SEM analysis of the smear layer thickness and surfaces prepared with diamond bur, tungsten carbide bur or \#600-grit $\mathrm{SiC}$ paper. A flat dentin surface parallel to the occlusal surface was exposed and prepared as was the occlusal surface for the microtensile bond strength test (six teeth for each dentin surface preparation).

All samples were fixed in Karnovsk's solution, dehydrated in ascending concentrations of ethanol and critical point dried (CPD 030, Balzers, Liechtenstein). Three specimens of each dentin surface preparation were immersed in liquid Nitrogen and then fractured with a sharp blade positioned into an edge created on the specimen. The fractured sides of specimens and the other prepared occlusal surfaces were sputter gold coated (MED 010, Balzer, Leichtenstein) and examined under SEM (VP 435, Leo, Cambridge, England) at $20 \mathrm{kV}$.

\section{RESULTS}

Table 1 shows the mean tensile bond strengths and standard deviations for the experimental groups. Two-way ANOVA revealed that there were statistically significant differences for the factor "surface treatment" ( $p=0.00003)$, for the factor "adhesive system" ( $p=0.01468)$ and for factor interactions $(p=0.00001)$.

The Tukey test showed that the surface treatment affected the tensile bond strength only for Clearfil SE Bond $(p<0.05)$. The bond strength of Clearfil SE Bond to dentin surfaces prepared with tungsten carbide bur was lower than that of surfaces treated with diamond bur or \#600-grit $\mathrm{SiC}$ paper, which did not differ between them. The bond strength of One-Up Bond F to dentin surfaces was

TABLE 1 - Means (MPa) and standard deviations obtained for the tested groups.

\begin{tabular}{l|c|c}
\hline \hline & Clearfil SE Bond & One-Up Bond F \\
\hline Diamond Bur & $24.93 \pm 7.93 \mathrm{Aa}$ & $14.57 \pm 5.02 \mathrm{Ab}$ \\
\hline $\begin{array}{l}\text { Tungsten } \\
\text { Carbide bur }\end{array}$ & $17.50 \pm 7.08 \mathrm{Ba}$ & $13.50 \pm 1.80 \mathrm{Ab}$ \\
\hline $\begin{array}{l}\text { SiC Abrasive } \\
\text { Paper }\end{array}$ & $28.49 \pm 6.99 \mathrm{Aa}$ & $17.23 \pm 5.73 \mathrm{Ab}$ \\
\hline \hline
\end{tabular}

Different letters indicate significant differences (column = capital letter; line = lower case letter). not affected by surface treatment $(p>0.05)$. Dental burs and $\mathrm{SiC}$ paper dentin surface treatments promoted similar bond strengths for One-Up Bond F. The tensile bond strength of Clearfil SE Bond was higher than that of One-Up Bond $\mathrm{F}$ for all dentin surface treatments $(p<0.05)$ (Graph 1$)$.

Figures $1 \mathrm{~A}, 1 \mathrm{~B}$ and $1 \mathrm{C}$ consist of SEM analysis of dentin surfaces prepared with dental drills and \#600-grit SiC paper. Specimens prepared with the diamond bur exhibited an irregular and rough surface, with deep and irregular grooves (Figure 1A1). The diamond bur produced a thick smear layer occluding the dentinal tubules (Figure 1A2). When prepared with the carbide bur, dentin surfaces showed narrow and short grooves (Figure 1B1). The carbide bur produced a thin and irregular smear layer with particles occluding the dentinal tubules (Figure 1B2). Specimens prepared with \#600-grit SiC paper exhibited narrow and uniform scratches on a flat surface (Figure 1C1). The SiC paper formed a thin and regular smear layer with large smear plugs obliterating the dentinal tubules (Figure 1C2).

Most of the fractures examined under SEM occurred within the adhesive or hybrid layers (Figures 2 and 3). When Clearfil SE Bond was applied, the dentin surface prepared with either diamond or carbide bur exhibited some sites appearing to be the hybrid layer or even a hybridized smear layer, and other sites appeared as hybridized dentin with resin tags occluding the dentinal tubules (Figure 2A and 2B). However, for specimens treated with OneUp Bond F, the fractured surfaces exhibited areas

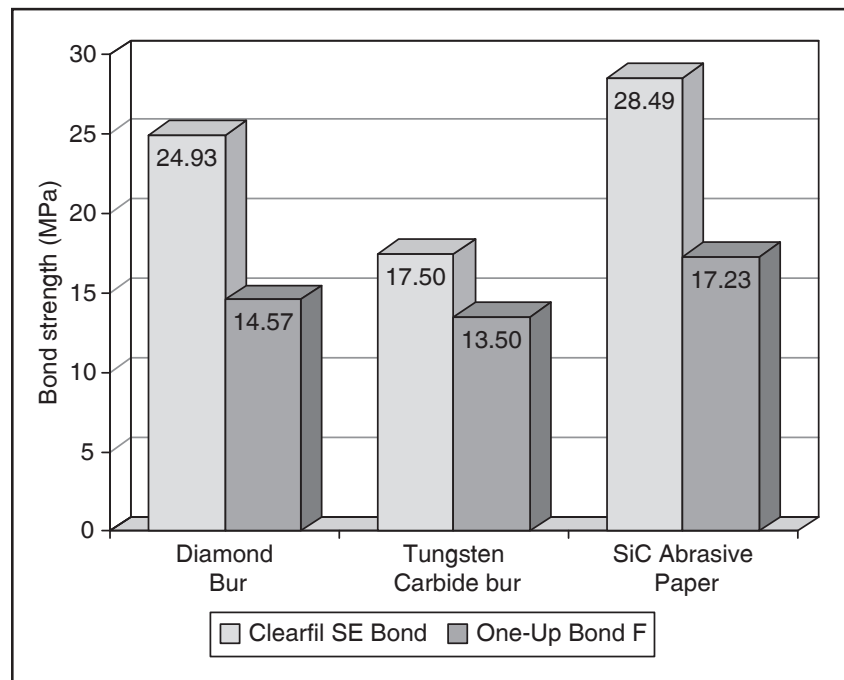

GRAPH 1 - Bond strength (MPa) of adhesive systems to dentin. 
Rocha PI, Borges AB, Rodrigues JR, Arrais CAG, Giannini M. Effect of dentinal surface preparation on bond strength of self-etching adhesive systems. Braz Oral Res 2006;20(1):52-8.
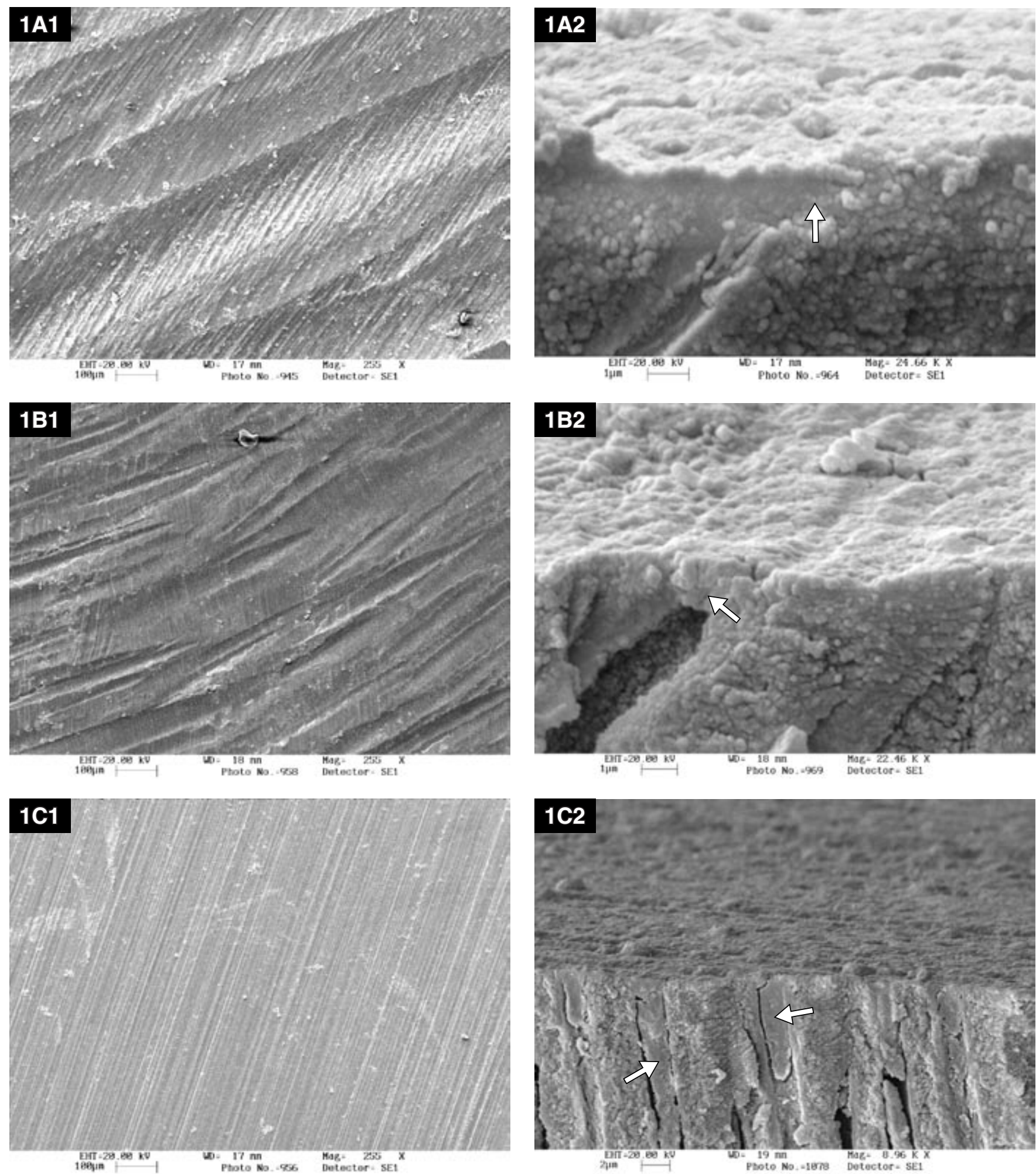

FIGURE 1 - SEM micrographs of dentin surfaces prepared with the diamond bur, the carbide bur and \#600 grit SiC paper. An irregular rough surface with deep and uniform grooves can be noted when dentin was prepared with the diamond bur (1A1). The thick smear layer occludes the dentinal tubules (1A2 - arrow). When prepared with the carbide bur, dentin surfaces showed narrow and short grooves (1B1) with particles occluding the tubules (1B2 - arrow). Narrow and uniform scratches can be observed on the flat surface prepared with the \#600 grit SiC paper (1C1). The smear plugs are obliterating the dentinal tubules (1C2 - arrows). 
Rocha PI, Borges AB, Rodrigues JR, Arrais CAG, Giannini M. Effect of dentinal surface preparation on bond strength of self-etching adhesive systems. Braz Oral Res 2006;20(1):52-8.
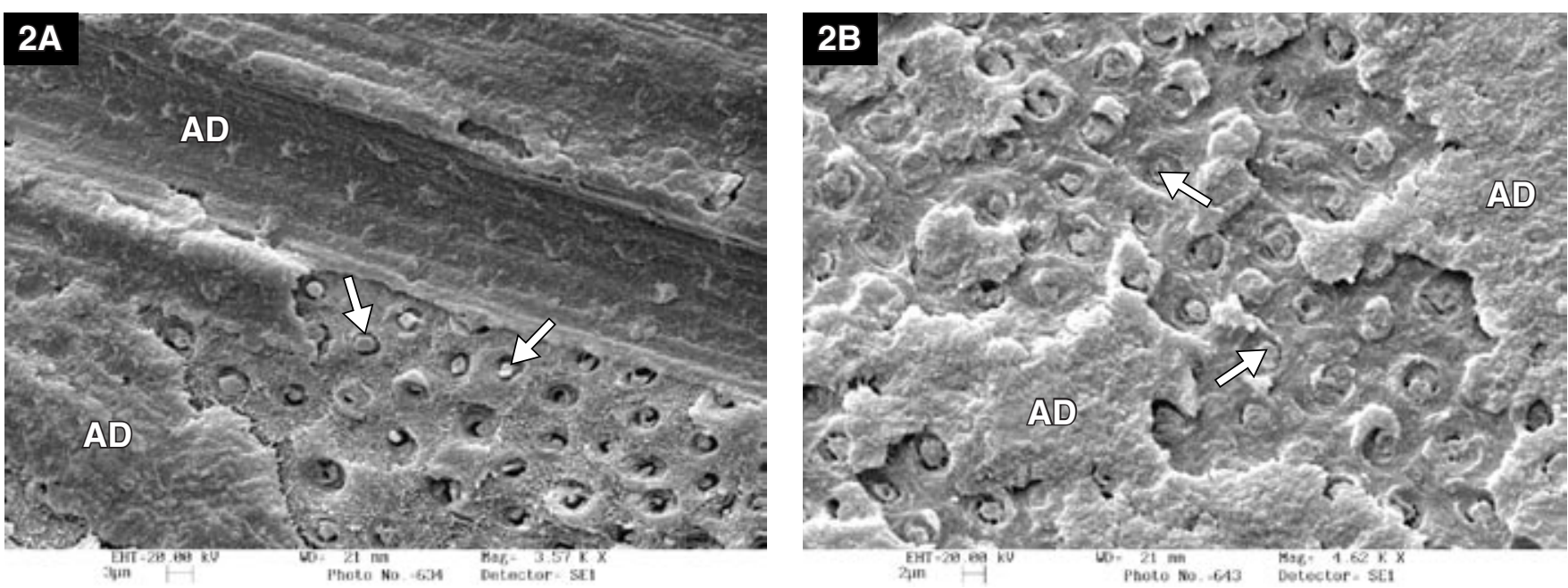

FIGURE 2 - Representative SEM micrographs of fractured surfaces prepared with the diamond bur (2A) or carbide bur (2B) and restored with Clearfil SE Bond. Fracture occurred cohesively either within the adhesive or the hybrid layer. Some sites exhibited a hybridized dentin with dentinal tubules occluded by resin tags (arrows), while there were sites showing an adhesive layer or hybridized smear layer (AD).
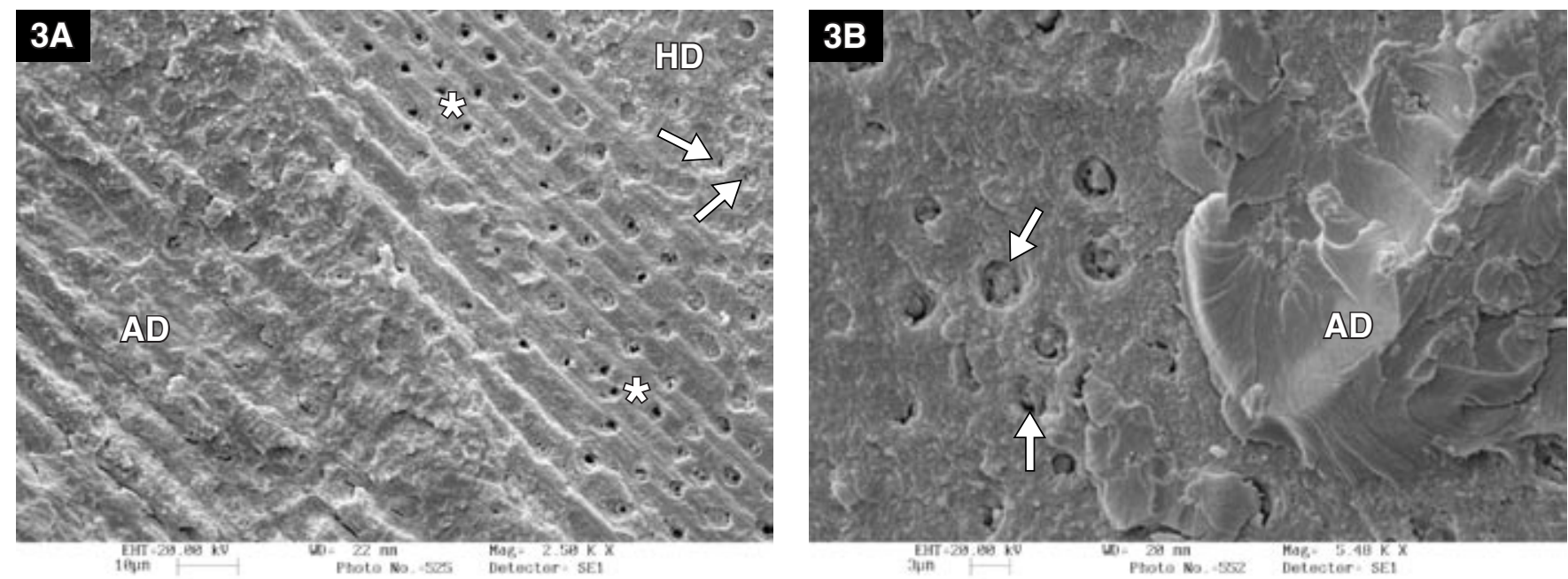

FIGURE 3 - Representative SEM micrographs of fractured surfaces prepared with the diamond bur (3A) or the carbide bur (3B) and restored with One-Up Bond F. The fractured surfaces exhibited some areas of dentinal tubules opened (asterisk - 3A) and hybridized dentin (HD) with many tubules occluded by hybridized smear plugs (arrows - 3A and $3 \mathrm{~B})$ and the adhesive layer (AD - 3A and $3 \mathrm{~B})$.

with some dentinal tubules opened, while other areas exhibited hybridized smear plugs occluding the entrance of the dentinal tubules (Figure 3A). This aspect was also observed when One-Up Bond $F$ was applied to the dentin surfaces prepared with the carbide bur (Figure 3B).

\section{DISCUSSION}

The results of the present study demonstrated that the method of surface preparation affected, in part, TBS of self-etching adhesive systems. According to our results, the effect of dentin surface preparation on TBS depended on the type of self-etching adhesive system. TBS was affected by dentin surface preparation only when Clearfil SE Bond was used after surface preparation with the tungsten carbide bur. In this case, a smear layer was created as thin as that created by the \#600-grit SiC paper (Figure 1B2), but with deposition of dentin particles with irregular sizes. When observed under SEM, the dentin surface prepared 
Rocha PI, Borges AB, Rodrigues JR, Arrais CAG, Giannini M. Effect of dentinal surface preparation on bond strength of self-etching adhesive systems. Braz Oral Res 2006;20(1):52-8.

with the carbide bur exhibited irregular, shallow, narrow grooves and dentin micro-particles deposited together with the smear layer ${ }^{5,12}$ (Figure 1B1). Analysis of the fractured specimens demonstrated that the adhesive monomer was able to infiltrate through the smear layer and hybridize the underlying dentin (Figure 2B). However, the presence of grooves and particles might have impaired the adhesive infiltration into some areas, reducing the TBS of the teeth prepared with the carbide bur and bonded with Clearfil SE.

On the other hand, dentin surfaces prepared with the diamond bur did not affect TBS when Clearfil SE Bond was used. The diamond bur created a thicker smear layer than did other treatments, and formed a rough dentin surface with deeper and uniform grooves, different from those created by the carbide bur ${ }^{1,4}$ (Figures $1 \mathrm{~A} 1$ and 2B). Evaluating dentin permeability before and after application of Clearfil SE Bond, Vaysman et al. ${ }^{18}$ (2003) observed that the highest reduction in bonded dentin permeability and an increase in sealing ability occurred when the self-etching adhesive system was applied to the roughest dentin surface. These authors affirmed that the high surface roughness might have increased dentin surface area, allowing a better contact between adhesive and dental substrate.

The results of TBS for Clearfil SE Bond are conflicting with those of previous studies, in which the use of the diamond bur affected TBS regarding the adhesive system ${ }^{9,10}$. Also, Oliveira et al. ${ }^{11}$ (2003) observed that the shear bond strength of teeth bonded with Clearfil SE Bond was lower only when the diamond bur used was coarser than the medium or fine one. Therefore, it may be difficult to compare results of different studies due to the differences in dental drill brands and coarseness tested.

TBS for One Up-Bond $F$ was lower than that for Clearfil SE Bond independently of the dentin surface preparation. Evaluating nanoleakage of One-Up Bond F by Transmission Electronic Microscopy, Reis et al. ${ }^{14}$ (2004) observed a high deposition of silver grains within either the hybrid layer or the adhesive layer after storing the specimens

\section{REFERENCES}

1. Al-Omari WM, Mitchell CA, Cunningham JL. Surface roughness and wettability of enamel and dentine surfaces prepared with different dental burs. J Oral Rehabil 2001;28(7):645-50. in water for a short period. The reticular mode of nanoleakage observed in those layers was attributed to areas in which water was present after adhesive photo-activation. Thus, the residual water within the adhesive layer may lead to domains of incomplete polymerization of the adhesive, compromising its mechanical properties ${ }^{13}$ and consequently its TBS, as observed in this study for all surface preparations.

Despite the higher $\mathrm{pH}$ when compared to the $\mathrm{pH}$ of phosphoric acid, the acidic primers need to permeate through all of the smear layer to reach the underlying dentin. However, these mild acidic primers are not able to completely remove the smear layer ${ }^{17}$, originating a hybridized smear layer. Koibuchi et al. ${ }^{6}$ (2001) have suggested that the weakest point in specimens bonded with self-etching adhesive systems was within this hybridized smear layer. SEM micrographs of the fractured specimens exhibited areas that may be a hybridized smear layer or a hybrid layer with remnants of the smear layer (Figures 2 and 3A). Therefore, the quality and quantity of the smear layer created by different surface preparation methods might be important factors when using self-etching adhesive systems ${ }^{10,11,17}$. The null hypothesis tested in this study was rejected when using Clearfil SE Bond adhesive system, but accepted when using One-Up Bond F.

\section{CONCLUSION}

The use of a tungsten carbide bur decreased TBS for Clearfil SE Bond, while dentin surface preparations did not affect TBS for One-Up Bond F.

\section{ACKNOWLEDGMENTS}

The authors are indebted to Prof. E. W. Kitajima (NAP-MEPA/ESALQ-USP - Núcleo de Apoio à Pesquisa em Microscopia Eletrônica Aplicada a Pesquisa Agropecuária, Escola Superior de Agricultura "Luiz de Queiroz", University of São Paulo) and to the Laboratory of Dental Materials (School of Dentistry, State University of Campinas). This study was supported by CAPES and by grant 03/08090-7 from FAPESP, Brazil.

2. Ayad MF, Rosenstiel SF, Hassan MM. Surface roughness of dentin after tooth preparation with different rotary instrumentation. J Prosthet Dent 1996;75(2):122-8. 
Rocha PI, Borges AB, Rodrigues JR, Arrais CAG, Giannini M. Effect of dentinal surface preparation on bond strength of self-etching adhesive systems. Braz Oral Res 2006;20(1):52-8.

3. Chaves P, Giannini M, Ambrosano GM. Influence of smear layer pretreatments on bond strength to dentin. J Adhes Dent 2002;4(3):191-6.

4. Eick JD, Wilko RA, Anderson CH, Sorensen SE. Scanning electron microscopy of cut tooth surfaces and identification of debris by use of the electron microprobe. J Dent Res 1970; 49(6 Suppl):1359-68.

5. Gwinnett AJ. Smear layer: morphological considerations. Oper Dent Suppl 1984;3:2-12.

6. Koibuchi H, Yasuda N, Nakabayashi N. Bonding to dentin with a self-etching primer: the effect of smear layers. Dent Mater 2001;17(2):122-6.

7. McInnes PM, Wendt SL Jr, Retief DH, Weinberg R. Effect of dentin surface roughness on shear bond strength. Dent Mater 1990;6(3):204-7.

8. Nakabayashi N, Saimi Y. Bonding to intact dentin. J Dent Res 1996;75(9):1706-15.

9. Ogata M, Harada N, Yamaguchi S, Nakajima M, Pereira PNR, Tagami J. Effects of different burs on dentin bond strengths of self-etching primer bonding systems. Oper Dent 2001;26(4):375-82.

10. Ogata M, Harada N, Yamaguchi S, Nakajima M, Tagami J. Effect of self-etching primer vs phosphoric acid etchant on bonding to bur-prepared dentin. Oper Dent 2002;27(5):447-54.

11. Oliveira SS, Pugach MK, Hilton JF, Watanabe LG, Marshall SJ, Marshall GW Jr. The influence of the dentin smear layer on adhesion: a self-etching primer vs a totaletch system. Dent Mater 2003;19(8):758-67.

12. Pashley DH, Tao L, Boyd L, King GE, Horner JA. Scanning electron microscopy of the substructure of smear layers in human dentine. Arch Oral Biol 1988;33(4):265-70.

13. Paul SJ, Leach M, Rueggeberg FA, Pashley DH. Effect of water content on the physical properties of model dentine primer and bonding resins. J Dent 1999;27(3):209-14.

14. Reis AF, Arrais CA, Novaes PD, Carvalho RM, De Goes MF, Giannini M. Ultramorphological analysis of resin-dentin interfaces produced with water-based single-step and two-step adhesives: nanoleakage expression. J Biomed Mater Res B Appl Biomater 2004;71(1):90-8.

15. Tagami J, Tao L, Pashley DH, Hosoda H, Sano H. Effects of high-speed cutting on dentin permeability and bonding. Dent Mater 1991;7(4):234-9.

16. Tani C, Finger WJ. Effect of smear layer thickness on bond strength mediated by three all-in-one self-etching priming adhesives. J Adhes Dent 2002;4(4):283-9.

17. Tay FR, Pashley DH. Aggressiveness of contemporary self-etching systems. I: Depth of penetration beyond dentin smear layers. Dent Mater 2001;17(4):296-308.

18. Vaysman T, Rajan N, Thompson VP. Effect of bur cutting patterns and dentin bonding agents on dentin permeability in a fluid flow model. Oper Dent 2003;28(5):522-8.

19. Wahle JJ, Wendt SL Jr. Dentinal surface roughness: a comparison of tooth preparation techniques. J Prosthet Dent 1993;69(2):160-4.

Received for publication on Sep 19, 2005

Sent for alterations on Oct 31, 2005

Accepted for publication on Jan 09, 2006 